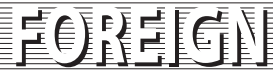

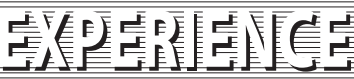

\section{AGGLOMERATIONS AS STRATEGIC ACTORS IN A GLOBALIZING WORLD}

\author{
Revekka M. Vulfovich \\ Doctor in Political Science, Professor of the North-West Institute of RANEPA. \\ Address: Russian Academy of National Economy and Public Administration. \\ 43/57 Sredniy pr. of Vassil'evskiy Island, 199178 St. Petersburg, Russian Federation. \\ E-mail: prof_vulf@bk.ru
}

Through its complex orchestration of time and space, no less than through the social division of labor,

life in the city takes on the character of a symphony: specialized human aptitudes, specialized instruments, give rise to sonorous results which, neither in volume nor in quality, could be achieved by any single piece.

(Mumford, L. 1938 / 1970, 4)

\begin{abstract}
Globalization has been changing the urban landscape rapidly in recent decades. Suburbanization, urban sprawl and intensive migration have transformed former territories with a mix of urban and rural settlements into huge high urbanized regions which play a key role in the development of nation states and macro-regions of the world.

They have also become sites for the concentration of problems such as terrorism, crime, ethnic conflicts, economic disparities, hatred and exclusion, because of their size and magnetism as points of prosperity.

The goal of this article is to show the historical process of agglomeration-building in Europe (e.g. Paris and Berlin), the USA (e.g. Tristate NY) and Russia (e.g. St. Petersburg, Samara - Togliatti Agglomeration) and to explore actual problems of strategic planning in these city-regions. The city-regions are analyzed within the frame of a holistic approach (top - down direction). Large city-agglomerations in Russia are, at present, possible motors of growth and development. The elaboration of strategies for them could be the starting point in the recovery of the economy and society. But the experience in this field is not broad enough to lead to positive and rapid results. This makes a comparative analyses of international examples extremely important for Russian governing bodies and social groups.

In the research we use statistical data - demographic, economic and political - to show the strengths, weaknesses, risks and opportunities of agglomeration development in the 21st century.
\end{abstract}

Keywords: agglomeration; strategic actor; strategizing; holistic approach; motors of growth; comparative analyses.

Citation: Vulfovich, R.M. (2016). Agglomerations as Strategic Actors in a Globalizing World. Public Administration Issues, no 5 (Special Issue, electronic edition), pp. 119-137 (in English). 
C 7 he idea that cities can be characterized as actors in a global economy 1 is controversial and has been conceptualized in many different ways" (Harding \& Blockland, 2014, p. 58). The 21st century has brought multiple challenges with it. Among these are the rapid growth and radical restructuring of the urban world. In the 20th century, in the industrial age, cities had already began to play a key role in a development of technics, culture, sciences and other aspects of human civilization. But the city form has been changing rapidly and in the past decades, suburbanization, urban sprawl and intensive migration have transformed former territories with a mix of urban and rural settlements into huge highly urbanized regions with dense populations and intensive relations of various kinds between settlements situated within their borders: political, economic, cultural and social. New means of transportation has made it possible to look at these regions as a whole of some kind and required the search for new organizational structures, principles, rules and mechanisms of governance.

To describe multiple sprawling urbanized landscapes and city networks researchers have been using various terms: including the much discussed "megalopolis" of Jean Gottman (Gottman, Megalopolis, 1961).... archipelago economy, galactic city, string city, limitless city, endless city, liquid city, global city region, world city-region, mega-city region, polycentric metropolis, new megalopolis, megapolitan region, metro region, polynuclear urban region, super urban area, super region.... mega region. All these termini are collected and interpreted by the authors of the book "Megaregions: Globalization's new urban form?" John Hurrison and Michael Hoyler (Hurrison \& Hoyler, 2015, p. 1) to show how different the views about the modern urban form and its specific character are. The main subject of this essay collection (published by Hurrison and Hoyler), about US, European and Chinese urban megaregions, is an urbanized territory developed more or less organically during a long period of history which is typically enormously competitive and progresses to a very "good quality of life" for its citizens. Megaregions are shown in the essays as actors able to cross administrative and political borders including borders of autonomous regions, subjects of federal states and even state borders as well.

Cities have been acting like this throughout history. The Hanseatic League, as a commercial and defense union of market cities, dominated the flow of goods in the Baltic Region through inter-city trading networks for four centuries (Harding \& Blockland, 2014, p. 57). The nodes of the network were cities not only in West and North Europe such as Hamburg but also in East Europe such as Novgorod.

In his famous book "The Culture of Cities" the American urbanist Luis Mumford prophesied a full decline and death of the city in the 20th century. For a city as a civilization phenomenon, Mumford outlined updating the six stages of evolution concept of his teacher Patrick Geddes (Geddes, 1915): Eopolis as a pre-city is not relevant today, but the second one - the Polis - being a settlements group comprising some social system with common economic, political, cultural and other functions is today mostly the core city of large agglomerations and huge mega-regions. For Aristotle and Plato, polis was the most significant element of the antic world-system. 
Of great importance in Mumford's classification is the Metropolis as the main city in a definite region and the last stage of development from his point of view. The largest metropolis' of the 21st century are world-cities or global cities of different size (mostly mega-cities with a population of tens of millions) and extremely high influence in the mega-regions of the world. Three other stages in Mumford's urban world picture are connected with decline and destruction. As a result, the Megalopolis, the Tyrannopolis and the Necropolis appear (Mumford, 1938 / 1970, pp. 285-292). But later, Jean Gottman's Megalopolis is not such a sign but a new form of urbanized area where agglomerations are growing together because of economic development and new means of transportation. The main factors influencing the urban processes are geography, history and the economy, but beside these are also social changes such as intensive migration. Migrants are attracted by cities like magnets and cities are growing faster.

In the 1960s the creator of the concept of "Ecumenopolis" (a city made up of the whole world, a planet wide city) Constantinos Doxiadis described the absolutely new urban form in his forecast made up for around 2050. Not nation states but rather cities had to become the main centers of development and everyday life. Among the modes of transportation in his works are not only cars (mostly drawn by electricity), and railways of different forms (mostly underground and elevated), but also low earth orbit spaceships. On the surface of the city the only host must be a citizen able to move freely on foot in clean ecological surroundings. (Doxiadis, 1968). The main feature of ecumenopolis is the freedom of a man to choose a place to live, to work and to have rest without any borders. Not all of Doxiadis' ideas have become reality but large agglomerations and the suggested mega regions are the first steps to the new planet-wide city.

All concepts show the difficulties and problems connected with the definitions of urban forms developed in the modern world. Even more complicated is the matter of a description of their size (territory and population), borders, structure, governance systems and estimating the role of a "city" in the processes of production, consumption, migration, development, socialization, functional and spatial integration, and differentiation.

For the purpose of our research we extract from the multiple and complicated urban world some rather compact, closely interconnected, densely populated territories and define them as agglomerations. The Russian urban researcher Georgy Lappo calls agglomerations "galaxies of cities" (Lappo, 2012, p. 92). The kind of relations and connections between cities and other settlements in agglomerations, from our point of view, can be expressed better with the term "constellations" showing close contacts which create possibilities for more intensive and rapid development of the area. The main characteristic feature of agglomerations is that they are not only territorial entities but also an uninterrupted process of development and change which has to be planned, organized and evaluated. Today, agglomerations play a role typical of cities in the classical meaning of the word since the antiquity and perhaps earlier, and untill the beginning of the last century. The city has not died. Its death in the "information age", according to the authors of the "Urban Theory" Alan Harding and Talja Blokland (Harding \& Blockland, 2014, p. 70), is much exaggerated. The city 
has changed radically but has remained a key actor in the 21st century. In the globalizing world where "the space of flows" is more developed than the "space of places", agglomerations as an "urban form" stay to be "important nodes" because the "space of flows is not placeless" (Castells, 2010).

It is not easy to find the starting point of agglomeration-building in the history of different city-regions. Most areas of such kind developed in the 20th century simultaneously with industrialization and intensive economic development. Concentration of firms and production sites required massive workforces and workers lived mostly in nearby smaller cities and other settlements.

At present, the Paris agglomeration includes eight departments of the Ill' de France region and its 465 communes (French municipalities). As a core of agglomeration the City of Paris had a starting point of its history in Roman epoch in a form of a military settlement. Later on, the city - Ville de Paris - developed as a market, as a political center of the French kingdom, and a cultural, economic and religious center. With the urbanization, industrialization and intensification of mobility, two "crowns" connected with the core were being formed intensively: the "small crown" - the first concentric ring around the department Paris nearer to the city consisting of three other departments (Hauts-de-Seine, Seine-Saint-Denis, and Val-de-Marne) and the "large crown" which has four departments (Seine-et-Marne, Yvelines, Essonne, and Val-d'Oise). The next stage of the agglomeration process took place after World War II when "New towns" were built to absorb the growing population in order to prevent overcrowding of the capital city.

At that time the Paris agglomeration within the Ill' de France region limits had a population of more than $12,005,077$, or 18.2 percent of the population of France (Estimation de population, 2014). But new developments took place just at the beginning of this year. On the $1^{\text {st }}$ January 2016 an absolutely new territoriality was born - the Métropole du Grand Paris with four departments - Paris, Hauts-de-Seine, Seine-Saint-Denis and Val-de-Marne; plus seven communes in the outer suburbs, including Argenteuil in Val d'Oise and Paray-Vieille-Poste in Essonne, which were added to include major airports. Grand Paris covers 814 square kilometers and has a population of 6.945 million people. (Scruggs, The "Grand Paris" era begins, 08.01.2016).

Besides this, we must not forget the Paris Metropolitan area which plays an important role as a statistical area showing the reach of commuter movement to and from Paris and its surrounding suburbs, has a population of 12,405,426 and extends the territory of the Ill' de France region. In reality, the borders of the agglomeration are moving with the growth of the population and with the development of the transport facilities, making it possible for the citizens to go further and further in search of workplaces and different services.

The three-state metropolitan region around New York City is even larger with an estimated population within the Metropolitan statistical area of 20,182,305 (Annual Estimates, 2015) and within the Combined statistical area of 23,723,696 (the same). The first entity includes 25 counties of the states of New York, New Jersey and Pennsylvania. The second is referred to as a Tri state region with 33 counties of the states New York, New Jersey and Connecticut. In reality, the economic and 
social interconnections are most dense in the region of the Combined statistical area. The core city, founded in 1624 before the creation of the states and the USA as a whole, was transformed into the municipality in 1898 with the consolidation of Brooklyn (until then a separate city), the County of New York (which then included parts of the Bronx), the County of Richmond, and the western portion of the County of Queens (The 100 year anniversary of the consolidation of the 5 boroughs into NY city was in 1998). The opening of the subway in 1904, first built as separate private systems, helped to bind the new city together. Throughout the first half of the 20th century, the city became a world center for industry, commerce, and communication uniting five counties. Thousands of migrants have been striving for the "Big Apple" during for decades and have brought their cultures, religions, languages with them. Currently 800 languages are spoken in the city. The region was already seen as a whole at the beginning of the last century and the fourth "Regional plan" for the Three-State NY is already on the way and has to be accepted in 2017. The Three-State NY is a statistical area but its importance in the development of this part of the USA has grown immensely through time because of the intensive work of the Regional Planning Association (RPA) making all possible efforts to harmonize the quality of life and living conditions in all municipalities and parts of the region. The RPA as a union of science, business, policy, ecological thinking and citizens participation is "transcending election cycles, partisan interests, state borders and human prejudice in its work" (Shaping the Region, 2014, p. 3).

At present, the Metropolitan Statistical Area of New York is one of the most populous agglomerations in the world. It makes the administration and policy making problems in the region extremely complex and the role of the region, in the USA, on the American continent and in the world, enormous. The experience of strategic planning in the region covers about 100 years and is an exclusive example of developing strategic plan and implementing it in a very rare regime of subsidiary policy-making with leadership taken by local business and research, communities and citizens.

Greater Berlin was united within actual borders in the 1920s and includes many former cities which had already existed in the Middle Ages. The first steps in this direction were already made before World War I. In 1912 the 'special purpose alliance was created to solve the problems of economic and infrastructural development. Due to the activities of the Alliance, large parks such as Tiergarten, Treptower Park and others have survived in Berlin. The intensive necessity of Berlin's cooperation with other municipalities around it is evident in the history of the Berlin underground (Untergrundbahn). At the very beginning, this transportation system was built separately in different parts of the region. And only after the establishment of the Greater Berlin municipality in 1920 did the construction of the rationally organized mass transportation system for the entire region become possible.

The unification of Berlin with its surroundings was a complicated political procedure in the Prussian parliament and the decision was made after a severe struggle between the left oriented social-democrats and independent democrats, right oriented national parties and the party of Center. The result of the 
struggle was a compromise and in the municipality of Greater Berlin the districts - former city-municipality - parlty maintained their autonomy. Nowadays, the size of the agglomeration has become larger and the region is estimated within different borders. The agglomeration includes the territory of Berlin and 50 municipalities of Brandenburg situated near the city-state as well as the capital city of Brandenburg - Potsdam - and has a population of 4,470,000. In 1995 the political unification of both subjects of the German Federation, Berlin and Brandenburg, was planned and prepared but did not happen. Besides the entity of the agglomeration, the Berlin/Brandenburg metropolitan region exists as a statistical unity comprising both Länder with all their municipalities. The Berlin city-state is the core of the region and influences all processes and affairs on the territory as Germany's capital city, the largest city in the country and the political, economic and cultural metropole in this part of Europe. According to Eurostat statistics the capital region Berlin-Brandenburg is even larger.

In Russia, nobody considered the regions of large cities as integral systems with special features and functions during the Soviet period. Cities were only meant to be production sites and industrial centers.

In the second decade of the 21 st century, in Russian law there are still no such terms as "agglomeration" or "metropolitan region (area)", which is considered by many researches and practitioners in the field of planning and public government as the lack of a legal base for the development of Russia's urban regions (Shchitinskiy, 2013).

St. Petersburg (former Leningrad) has been developing since 1917, originally as an industrial center of military production. But since the first days of its existence, very near to the city smaller cities and towns were built as summer residences, fortresses and industrial centers. They exist today and their key role remains - connection with the core and carrying out multiple functions for it: living, safeguarding the history, developing sciences and arts, and the production of goods and services. At present nine cities (Petrodvorets, Lomonosov, Pushkin, Pavlovsk, Sestroretsk, Zelenogorsk, Kolpino, Kronstadt and Krasnoje Selo) and 21 other settlements are parts of St. Petersburg - one of 85 subjects of the Russian Federation, the so called federal city - autonomous municipalities but also parts of the city's administrative districts.. We can characterize the second largest city of Russia also as a city-state like Berlin because of its competences in the federal state.

The second group of cities in the St. Petersburg agglomeration are politically parts of another subject of the Russian Federation - the Leningrad Region situated around the city-state. The boundary between both subjects makes the unification and complex development of the agglomeration as an entire system a complicated matter: it is not absolutely clear where this border is situated and it is not marked politically or administratively. So the agglomeration does not exist as a definite territory with an economically or socially knitted-together system. Districts of the Leningrad Region such as Vsevolozhskij, Gatchinskij, Kirovskij, Tosnenskij, Lomonosovskij and (less so) Vyborgskij (6 from 17) are generally included into the agglomeration, whereas others are seen as a remote periphery not important for further development. 
The differentiation of the region's districts according to their importance to the city-state makes the integration of the agglomeration more difficult and the merging of both regions seem not possible. Remote territories fear that they will not be developed at all and their resources will be used by the city-state for its own needs.

Besides the mononucleus agglomerations in the world there are many multinucleus conurbations, also called "polycentric" (Pain, 2015), where two or more large cities unite the territory into the system and create a highly urbanized region with more opportunities for economic development and social cohesion.

In the early 21 st century, agglomerations also became an important issue in Russia because of the development problems connected with the most relevant features of the country: the largest territory in the world, a relatively small and diminishing population, and the necessity for rapid development of economic, infrastructural and social subsystems. Which was why strategic plans and other concepts were developed in different parts of Russia. One such concept was devised in the Samara region (oblast) for a territory between Samara and Togliatti along the Samara bend. The key centers of the region over a distance of about $170 \mathrm{~km}$ are the six cities - Samara, Togliatti, Chapayevsk, Novokuybyshevsk, Zhygulevsk, Syzran - plus six other towns. The total population is more than 2.7 million.

In a research report from the "Giprogor" Institute, the conurbation is described as a "densely populated area consisting of the highly developed Samara agglomeration, the little developed Togliatti agglomeration, the developing Syzran agglomeration and the natural recreation resort of the Samara bend" (Institut Giprogor, 2011). On 30 August 2016, eight city-districts and nine municipal districts of the Samara region signed an agreement with the Regional government about the cooperation and development of the agglomeration. The signing partners were the cities Samara, Togliatti, Syzran, Novokuybyshevsk, Chapaevsk, Zhygulevsk, Octyabrsk, Kinel, and the municipal districts of Bezenchuksky, Volzhsky, Kinelsky, Krasnoarmeysky, Krasnoyarsky, Privolzhsky, Stavropolsky, Syzransky and Shigonsky (Aleshin, 21.09.2016).

One of the most relevant factors of influence for conurbation building is the competition between the Samara Region and the Republic of Tatarstan - one of the most developed regions of Russia. The city of Samara is unable to compete with the cities of Tatarstan, particularly the capital city Kazan. But the economic power of the conurbation including Samara, Togliatti and Syzran can help the region to develop more rapidly and intensively to match competitors in other parts of the Volga mega-region.

The importance of agglomerations for the national and, subsequently, global economy can be illustrated with the percentage of GDP produced in the regions. For the Ill' de France region, it is estimated as 30\%, for the New York Combined Statistical Area - 8.3\%, for the Metropolitan Region Berlin/Brandenburg $-5.1 \%$, and for St. Petersburg (in the borders of the Subject of the Russian Federation) - 12\%. With the growth of the urban region's territory, the population and the production grow and the functions become more multiple and diverse. 
The highly urbanized regions described above have many differences but one common characteristic feature is the most important for our research. It is their strategic role in the development of their hinterland, countries and megaregions of the world. From this point of view, the new type of the urban policy and politics has to be analyzed within the frame of a"holistic" approach. The decision making in an agglomeration is not exactly the same as in a separate city. The interests, approaches and possibilities differ greatly. "The social, the cultural, the political, the natural and the economic" (McCann \& Paddison, 2014 , p. 220) dimensions within the agglomeration create the space with more than only three classic dimensions (width, breadth and length) thought typical for the territorial objects. First of all, the space of an agglomeration includes time as a very important factor, and also the political will of governing bodies and groups, and besides this there is individual rationality.

The infrastructure that has created Castells' "space of flows", in other words, is likely to have been superimposed upon an earlier "space of places". Some places have been better able to adopt it than others. "Thus, people do still live in places. But because function and power in our societies are organized in the space of flows, the structural domination of its logic essentially alters the meaning and dynamic of places. The dominant tendency is toward a horizon of networked, ahistorical space of flows, aiming at imposing its logic over scattered, segmented places, increasingly unrelated to each other, and less and less able to share cultural codes. Unless cultural, political, and physical bridges are deliberately built between these two forms of space, we may be heading toward life in parallel universes whose times cannot meet because they are warped into different dimensions of a social hyperspace (Castells, 2010, pp. 458-459).

The hypothesis of the hyperspace developed by physicists (Kaku, 1994) and mentioned by Manuel Castells in his works (Castells, 2010, p. 407) makes it possible to explore the space of agglomeration as the space of flows and to find out the multiple forces whose influence is creating a new power constellation typical for the information society of the 21 st century.

In the indefinite surroundings of transforming states, like Russia, such analysis is very difficult because of rapidly changing interaction rules and the absence of stable goals and organizations to fulfil the developed programs and strategies. But in all of the agglomerations during recent decades, some common features have become most important:

1. The information society created space where the flows of a different kind have become more important as places as such. The generation of social space (Castells, 2010) happened through the development of new facets never seen before because of the objective impossibility of their existence in former times. Not only have megacities become magnets and centers of economic and political development with the appearance of new organizational forms and modes of human behavior, but also large cities in their regions with less dense population and settlement networks.

2. Most important processes in modern development, technology and scientific innovations are developed and transformed in places with concentrated flows of information and communication. And nobody denies the role 
of large agglomerations as nodes for this flow. The core city can sometimes not be the most suitable place for producing advanced services typical for the new information society because of the high expenses, but the nearby settlements can play the role of supplementary areas.

3. New transportation modes are needed to knit the agglomerations together and are developed everywhere. Rail plays a leading role as before but the speed is becoming so high (up to $400 \mathrm{~km} / \mathrm{h}$ ) that the space and time are compressed and it is already possible to live hundreds kilometers far from the core city and still feel like a citizen.

4. Space is crystallized time. Time and space cannot be understood independently of social action (Castells, 2010, p. 441).

5. Three layers in the space of flows play a defining role in modern agglomerations: the material support of the space of flows is actually constituted by a circuit of electronic exchanges; the second layer is constituted by its nodes and hubs hence the space of flows is not placeless; the third important layer to the spatial organization of the dominant, managerial elites (rather than classes) (Castells, 2010, p. 444-445).

Time and space, which are the strongest factors distinguishing the urban world, are characterized by researchers and practitioners working in the field of strategizing as the main principles for developing and implementing every kind of strategy. "... analyses shows that the ruling dominant law of strategy is different from the ruling law of politics or economy... In strategy, however, the major law is the law of time.... A time-sensitive analyses of a strategy is a criterion that must always be in place through the development and implementation of all elements of any strategy.... Analyzing the strategic practice proves Napoleon's point of view that the two most important criteria of the strategic decision-making process are time and space" (Kvint, 2016).

Different sorts of socio-spatial connections and differences, movements and immobilities are fundamentally about power (McCann \& Paddison, 2014, p. 221). This idea is also relevant for large agglomerations. Their size makes them centers of political and economic power. All chosen examples demonstrate the rightness of the thesis. New York City is one of four global centers with stock exchanges and other financial institutions functioning 24 hours a day, producing multiple services and activities unique to the modern world.

The notion of the "global city" is more a symbol, an imagination than the real territory. "The global city is a process rather than a place" (Castells, 2010, p. 443). The 8 million population of New York City could never have a large enough work force to produce all the products and services now connected with the financial, economic and political center of the USA, North America and the world. Only the Tri-state region with its 20 million is large enough to play the key role in a world as a global city and to be one of the global players in world politics. The same can be said about Paris. In competition with London, Tokyo and NY, the municipality of Ville de Paris would not stand a chance.

The researches of the "Globalization and World Cities Study Group GAWC" from Loughborough University (UK) (Globalization and World Cities Research Network) suggested the empirically proven modern classification 
of world cities on the basis of a score system evaluating four types of city functions: accounting and audit, advertising, financing and banks, insurance. All cities are grouped into four ranks and 12 categories $-\boldsymbol{\alpha}, \boldsymbol{\beta}, \boldsymbol{\gamma}, \mathbf{d}$. New York is among the most powerful "world cities" $\alpha++$, Paris belongs to the category $\alpha+$, Berlin $\beta+$, St. Petersburg $-\gamma+$, Samara is not presented in the classification.

Entertainment, cultural services, tourism, recreation and other services typical for world cities sometimes become as important as finance and insurance branches. Not occasionally, St. Petersburg has been competing in recent years with such famous European touristic centers as Paris, London, Barcelona and others for the title of leading tourist destination and won the first place in 2015 and 2016 (World Travel Awards, 2016). Among the strategic goals of the cities, the sustainable development of the surrounding region - the territory of agglomeration - often means not only the preservation of natural resources for future generations but also the development of different economic branches such as cultural and ecological tourism, different kinds of recreation, and ecology as a new technological sphere.

As examples of interconnection of the core city and the region around it in agglomeration, we analyzed different projects for preserving natural areas and park space in a core as well as in the regions. Such measures were foreseen already in the First Regional Plan for Tri-State New York, in the documents of the special purpose alliance in Berlin, and in the development plans of Greater Paris where the new entity, The Metropole of Grand Paris, was created in 2016, primarily for economic reasons but also for ecological cooperation. In Russia, the problem also must be solved in the regions of large cities. Around St. Petersburg, the "garden cities" of former imperial residences must be preserved not only as objects of historical heritage but also as resorts and places where the recreation industry can be developed as a leading economic branch. One of the pearls of the upcoming "Samara agglomeration" is the famous Samara bend and one of the largest and best known Russian rivers - the Volga.

The urban-rural distinction in agglomerations gains new qualities. It declined of importance through the age of industrialization. "In an urbanized world urban is everywhere and nowhere" (Harding \& Blockland, 2014, p. 11). But nowadays the task of integrating both elements becomes more important and complicated. The footprints of large cities mean contamination of the earth's surface, air and water that have to be cleaned and restored to enrich the city-life with new colors, emotions, scents and sensations.

The concept of "world cities", first developed by John Friedman (Friedman, 1986) and later refined by Peter Hall, is of special importance for analyzing agglomerations. Hall's "world cities" (Hall, 1996) contain key political and related functions (national governments, professional organizations, trades unions, employers' federations, head-quarters of major companies), major centers of trade (via major ports, road, rail and air infrastructure), key commercial functions (banks, insurances etc.), concentrations of professional services (health, law, higher education, research, media), and luxury consumption and entertainment functions (Harding \& Blockland, 2014, p. 77). All of them naturally were and are agglomerations because of their size and structure. 
Since 1981, another notion used by the United Nations in connection with large agglomerations is the notion of a megacity (Population Reports, 1981, p. 38). With a population more than 10 million, they are structural agglomerations with many settlements within their borders. There were 37 megacities in 2015: in Europe - 5 including Moscow in 22nd place (population 16.9 million), London, and Paris in 32nd place (population 12.4 million). Urban territories such as Tokyo, Jakarta, Seoul, Karachi, Shanghai, New York City, Manila, Mexico City, Delhi, Beijing also fall into this category.

Economic and the political power are closely interconnected in the modern world. The networks of large cities often play a key role in the process of decision-making about global problems such as climate change, migration flows and ethnic conflicts.

For a long period "political scientists ... have tended to proceed on the basis that cities can be defined, however imperfectly, by the boundaries that are relevant to political decision-making; that is, by areas covered by a local or metropolitan government. Studies that required a broader focus have embraced other definitions such as a "travel-to-work area", a "standard metropolitan statistical area", a conurbation, a "functional urban region"..." (Harding \& Blockland, 2014 , p. 9). But nowadays examples show that different dimensions of regions surrounding large cities create new types of economic and political entities: autonomous regions, economic zones, and statistical areas with special administrative and political functions.

The problems of cities are considered crucial for mankind in the 21 st century - the first century where the urban population has exceeded the population of the countryside. The new agenda will be accepted by the UN Habitat III in October 2016 in Quito (Ecuador) (United Nations Conference on Housing and Sustainable Urban Development, 2016). The fulfillment of their territorial functions across administrative boundaries, acting as hubs and drivers for balanced sustainable and integrated urban and territorial development at all levels, creation of sustainable and inclusive urban economies, by leveraging the agglomeration benefits of well-planned urbanization, high productivity, competitiveness and innovation; reinvigorating long-term and integrated urban and territorial planning and design in order to optimize the spatial dimension of the urban form and to deliver the positive outcomes of urbanization, are seen as the main goals of agglomeration building and development.

In this context it should always be remembered that "... national economies are .... constellations of regional economies, each with a major city at its core, each requiring specific and customized strategies" (Harding \& Blockland, 2014, p. 59).

The experience of more developed cities is particularly useful for agglomerations in less developed and developing countries. Namely the development of three regional plans of Tri-State NY could play an important role as a pattern for Russian agglomerations where the strategizing is in an entirely new direction and is connected with a number of problems.

It appears that the agglomeration of huge masses of people and value in certain places only happens occasionally. In reality geographic and historical factors 
do influence the process intensively. Two leading drivers of population agglomeration in every case are the geography of the region and its history (Goerlich \& Mas, 2009). But nowadays the influence of both these factors can be moderated or strengthened by the development of strategies whose goals are sustainable growth and intensive development according to the interests of citizens in the region seen as a wholesome system. According to this idea, all of the large agglomerations in the world, particularly in developed countries, are creating and implementing strategic plans for the long term development of mostly large territories because it makes the urbanized region more competitive and at the same time sustainable.

A very early example of a strategy developed for a region with many different polities (states of the USA, counties and municipalities) was The Regional Plan published in 1926 as mentioned earlier. At that time it was nothing short of revolutionary to create a common rationality for a Tri-State Metropolitan region with a large population and many partisan interests, state and municipal borders, and human prejudices also mirrored in different election cycles. All the difficulties of the strategy development process had been overcome with the help of in-depth research, an interdisciplinary approach and building the partnerships of multiple actors of regional development, including political parties, civic organizations, business leaders and communities of other kinds. By that time, the mechanisms of civic engagement had been developed by the Regional Planning Association as the main leader of the process. The RPA is an independent, non-profit organization. During more than ninety years of its existence the Association has gained credibility not only in the New York region but also in many parts of the USA for its long and successful experience in the development and implementation of the three Regional Plans of Tri-State New York (Shaping the Region, 2011).

Regional strategies were not rare in the first decades of 21st century. In 2011 the "Innovation strategy" for the Metropolitan region Berlin/Brandenburg was developed by the Common Planning Authority for both subjects of the German Federation and accepted by the governments of both Länder. The cooperation between Berlin and Brandenburg was very important for the region as a whole because of the difficulties with the unification of Germany and the processes started afterwards: completion between Berlin and Brandenburg for businesses, the public and finance. The border between the two Länder became a hindrance for development. Besides that, Berlin as a large city and the capital of Germany could take advantage of Brandenburg's natural resources and at the same time stimulate further development of the neighboring Land. Now both territories are working together (Strategy Report. Metropolitan Region Berlin / Brandenburg, 2009) in some clusters - energetics, healthcare, optics, IT, media, creative industries, transportation, mobility, logistics. On the Brandenburg agenda there are also some specific clusters that are also relevant for Berlin, including provision production and supply, the metal industry, chemicals and synthetic materials, and tourism. The example of the Berlin/Brandenburg Metropolitan Region shows the need for cooperation within Metropolitan Regions comprised of two federal subjects without having their merger connected with many political-ad- 
ministrative difficulties. Some spheres are administrated by common authorities as was shown above with the example of developing the Innovative Strategy.

Another case of metropolitan development in the region with the core worldand global city is the Ile-de-France Region around the capital-city of France, Paris. The Île-de-France Region is historically seen as the natural surroundings of the capital and the domain of a king, existing already as a socio-economic entity since 6 May 1976 and having gained economic and political powers in the course of regionalization in the 1980s and 1990s. The integration in the region is very close but since 1 January 2016 the entity with a smaller area and population than the Ile-de-France Region. the so called Métropole du Grand Paris, was created with the main strategic goal of improved coordination between the core city and its suburbs. One of the ways to reach this goal is to roll out the massive expansion of the Paris Métro subway system to offer better mobility to citizens in the suburbs.

The process is very difficult and many observers are skeptical about the powers of the new local government level among the many others in the political system of France (communes, departments, regions). But according to the regulations, the Métropole du Grand Paris will be governed by an elected council (209 members) and the president, with the responsibility for such issues as housing, environmental protection and local planning. The latter being one of the most important from the point of view of strategizing.

With the creation of the new entity, Paris is among other cities of the world that are trying to develop more efficient territorial strategies to heighten the role of the agglomeration as a strategic center in the modern globalizing world. Paris is one of the most prominent cities not only in Europe but also in the world (global city a+). At the same time, the dimensions within the "city" borders Ville de Paris - are not large. A ring road follows the pattern of the medieval city walls and Paris' territory is in this case 7.5 times smaller than New York City and 15 times smaller than Greater London. The new entity is 7.8 times larger than the commune Ville de Paris and even larger than New York City. This means that new possibilities of development, especially in housing issues, are created. At the same time new transportation and environmental problems also appear.

The main idea of creating Métropole du Grand Paris, as articulated by Nicola Sarkozy in 2007 (Scruggs, 2016), was the integration of Paris with its suburbs to make possible unified decisions and hence develop more competitive strategies for the capital city of France, its main historical, cultural, scientific, administrative and service center.

Not all of the citizens of Paris and its suburbs are enthusiastic about the new development. They ask some important questions: whether the expansion of the territory will lead to territorial ghettoization and apartheid between rich and poor or drive gentrification and force the poorest to move further from the city center (Durieux, 2016).

If it seems that the problems of North American New York and European Berlin and Paris are not relevant to the large Russian urban centers it is totally wrong. The issue of economic development is closely linked to the problem of interconnection and knitting the core city or core cities with the adjusting 
territories, sometimes politically independent from the core (as in the region of St. Petersburg) but sometimes included into the same political entity (subjects of the federation such as Samara, Togliatti, Syzran and other settlements in the Samara Region) and is today on the agenda of the federal authorities, at both regional and municipal level.

First of all, the "Plan (agenda) of agglomeration development in the Russian Federation" (Mnisterstvo economitcheskogo razvitiiya, 2015) has to be mentioned. The draft was first developed by a working group of the Ministry for Regional Development which disappeared in September 2014. But today the document is once more causing public debate. On the huge territory of Russia, with its relatively small population and small population density, the concentration of the population in the most developed and prosperous centers is inevitable. These are the largest cities which, with their surroundings, most have a population in the agglomeration area ofmore than 1 million citizens. Both cities analyzed in this article are in this category.

During the last decade the "Strategy" for St. Petersburg, the second largest city in Russia, was developed twice. In 1997 the so called "Strategic plan for St. Petersburg" (Generalnyi sovet strategitcheskogo plana, 1995) was developed and accepted by the General Council of the Strategic Plan for St. Petersburg. A decision about the beginning of the work had been made at the City Conference on the 1st December 1996 and included broad civic participation as an important condition. The main strategic goals were "Creation of a favorable economic climate", "Integration into the world economy", "Improvement of the habitat", and "Creation of a favorable social climate". In the text the transformation of city economy was stressed. For the first time in the city's history, its own form of development had to be chosen by itself, identified without the dictate of the federal center and without counting on its help. The city has to find and establish its place in the world economy and on the postindustrial world map. The development of St. Petersburg as a gateway to Europe, as a cultural capital, as an open economy and as a safe city were set as strategic priorities. The Strategy declaration was signed by 143 members of the Council including the Governor of St. Petersburg, members of the Federal and Regional Legislations, authorities, members of civic organizations, top managers of private organizations and public institutions, famous scientists, and artists. However, implementation of the document was not consistent enough and sometime later it had almost been forgotten about.

That's why on 13 May 2014 the new "Strategy of economic and social development of St. Petersburg until 2030" (Komitet po economicheskoy politike i strategitcheskomu planirovaniyu Sankt-Peterburga, 2014) was examined and accepted with the resolution of the city government. The document was developed by a working group acting on behalf of the Department for Economic policy and Strategic Planning of St. Petersburg with the participation of researchers from different city organizations. Civic participation was organized over the Internet and many citizens expressed their opinion about the strategic goals and priorities. "The creation of public values, forming out and introduction of progressive ideas, St. Petersburg's development as a center of world cul- 
ture and international cooperation" (Ibid., p. 50) was formulated as a strategic mission. The mission is turned more towards the outer world and the general (strategic) goal of the document - more towards the citizens, civil society and business of St. Petersburg. It is aimed at ensuring a stable life quality for citizens, improvement and increase in the city's global competitiveness on the basis of national development priorities, sustainable economic growth and the results of technological innovations (Ibid., p. 64).

A move to the polycentric model has to become the key direction towards more efficient space development. It means the well-managed and coordinated formation outside the main central business district of St. Petersburg, an agglomeration sub centers system and horizontal connections between them not only within city-borders (not more than $10-15 \mathrm{~km}$ from the ring road - Kolpino, Pushkin) but also on the periphery (Ibid., pp. 119-120). The instruments of this development are the "Charts for complex territorial planning of St. Petersburg and the Leningrad Region", the new General plan for St. Petersburg (to 2035) on the basis of the socio-ecological approach and the strengthening of interconnections between both region's infrastructure (Ibid., p. 121). The problems and main tasks of the agglomeration development (planning, coordination, and infrastructure including the transportation system) are formulated in the Strategy but form only a small part of the document (Ibid., pp. 129-130).

Much more consistent ideas are expressed in another conception prepared by the political party "Yabloko" (Apple) under the guidance of G. Yavlinsky in 2014. On the first pages of the "Greater St. Petersburg. 21st century. Conceptual Development Strategy for Megapolis " it is stressed that the core city and its surroundings should be considered as a wholesome strategizing object where the decision making is not disturbed by administrative borders, i.e., the official responsibility zones of two subjects of the Russian Federation - St. Petersburg and the Leningrad Region. In this case the agglomeration can be developed to become a global communications center generating finance resources in a number of economic spheres and service branches, creating events for a world community through the cooperation of citizens, authorities, and different communities. The approach of the "Greater St. Petersburg. 21st century" is much less formal, centralized, brought from above and more oriented on modern values and needs than the "Strategy 2030" (Yavlinskiy, G., 2014).

A more complicated structure than mononucleus agglomerations is characteristic of conurbations with multiple subcenters inside of which there are other elements - every subcenter could be seen as a separate agglomeration, which is the case with the Samara - Togliatti conurbation consisting of the highly developed Samara agglomeration, the less developed Togliatti agglomeration and the developing Syzran agglomeration. In 2011 the "Giprogor" Institute conducted the research thought to be a base for the draft of a further agglomeration territorial development citing the words written in the 20th century by the famous economist Vasyli Leontief: "The effective functioning of the economy depends on the rational organization of the territory" (Institut "Giprogor" 2011, p. 13).

The future of the large area along the Samara bend of the Volga river is connected with the development of the territory as a whole. It will make the urban 
area more competitive in Russia and create possibilities for the region within the agglomeration borders and also for the subject of RF around it to find new directions of economic and social evolution on a larger scale (Europe, other continents, the world). In 2013 the working team including Russian and foreign experts developed a set of recommendations for working out an agglomeration building Strategy for the Samara region. The environment (primarily the preservation of natural resorts through creating a new urban structure), Transport and Mobility (in the cities it will be possible to improve the roads and public transport systems, and between them, with plans to use the fast commuter trains direct to the Kurumoch airport and between Samara and Togliatti and also to smaller settlements on the way), Business, Finance, and Territorial Development (according to the integral plan) were included as the main priorities (Mamaev \& Working Group, 2013, pp. 10-12).

\section{Conclusions}

All over the world one of the hindrances in the development of agglomerations is poor infrastructure. The problems of these systems plus the high improvement costs necessitate the need for special programs and resources for their implementation. It slows the speed of change and makes the agglomeration less competitive on all levels. The difficulties grow due to the complicated territorial structure and require new approaches to the structural organization not only of the territory as such but also of different processes within its borders.

Large cities in Russia have extra problems to be solved. The first is the absence of the legal idea of an agglomeration, which makes the dependence on several authorities from different parts of the region one of the most relevant factors influencing all decisions; the federal level, the level of the subjects of federation, and the municipal level each have their own interests which are not always identical with the needs of the agglomeration as a whole and its parts. The second important matter is the lack or full absence of experience in the field of strategizing and in such a case it is also very difficult for the core city and its agglomeration to define their strategic role in the world and to formulate priorities for further development.

Hence, for the St. Petersburg and Samara-Togliatti agglomerations it is extremely important today to analyze the actual situation and work consistently on the strategic documents in short-, middle-, and long-term perspectives. 


\section{REFRENCES}

1. Aleshin, S. (2016). Aglomeratsiya stanet lokomotivom rosta Samarskoy oblasti [The agglomeration will be the growth driver for the Samara Region]. Volzhskaya kommuna, 21.09. Available: http://www.vkonline.ru/content/view/120079/aglomeraciya-stanet-lokomotivom-rosta-samarskoj-oblasti (accessed: 26 September, 2016).

2. Population Estimates (2015). Annual Estimates of the Resident Population: April 1, 2010 to July 1, 2015. Metropolitan Statistical Area; and for Puerto Rico.

3. Castells, M. (2010). The Rise of the Network Society. Chichester, West Sussex, UK: John Wiley \& Sons Ltd.

4. Doxiadis, C. (1968). Ecumenopolis: Tomorrows City. Available: http://www.doxiadis. org/Downloads/ecumenopolis\%20tommorow’s\%20city.pdf (accessed: 26 September, 2016).

5. Geddes, P. (1915) Cities in Evolution. An Introduction to the Town Planning Movement and to the Study of Civics. London: Williams \& Norgate.

6. Estimation de population au 1er janvier, par région, sexe et grande classe d'âge (2014). Available: http://www.insee.fr/fr/regions/ (accessed: 26 September, 2016).

7. Friedman, J. (1986) The world city hypothesis. Available: https://vk.com/doc523 5947_199788348?hash=f48c094926342dcf67\&dl=03ad6a96f86058ce5d (accessed: 26 September, 2016).

8. Generalnyi sovet strategicheskogo plana [General Council for the Strategic Plan] (1995). Strategicheskiy plan Sankt-Peterburga [Strategic Plan for Saint-Petersburg]. Available: http://docs.cntd.ru/document/9111170 (accessed: 26 September, 2016).

9. Globalization and World Cities Research Network. Available: http://www.lboro.ac.uk/ gawc/ (accessed: 26 September, 2016).

10. Goerlich, F. J. \& Mas, M. (2009). Drives of agglomeration: Geography vs History. The Open Urban Studies Journal, no 2, pp. 28-42.

11. Gottman, J. (1961). Megalopolis. NY: The Twentieth Century Fund.

12. Harding, A. \& Blockland, T. (2014). Urban Theory. London, etc. Sage Publications Ltd.

13. Hall, P. (1996). Globalization and the World Cities. UNI IAS Working Paper. Available: http://archive.ias.unu.edu/resource_centre/UNU-IAS\%20Working\%20Paper\%20 No.12.pdf (accessed: 26 September, 2016).

14. Hurrison, J. \& Hoyler, M. (2015). Megaregions: Globalization's new urban form? Chaltenham: Edward Elgar Publishing Ltd.

15. Institut "Giprogor" (2011). Analiticheskiy Doklad. "Arkhitekturnye osnovaniya territorialnogo planirovaniya $v$ Samarskoy aglomeratsii" [The Institute "Giprogor" Analytical 
Research Report. The architectural substantiation of the territorial planning document for the Samara agglomeration]. Available: https://www.google.ru/url?sa=t\&rct=j\&q= \&esrc $=$ \&\&source $=$ web \&cd $=1 \&$ ved $=0$ ahUKEwiO4uabop7PAhVmD5oKHdnnDR0QF ggcMAA\&url=http\%3A\%2F\%2Fminstroy.s (accessed: 26 September, 2016).

16. Kaku, M. (1994). Hyperspace. A Scientific Odyssey through Parallel Universes, Time Warps, and the Tenth Dimension. NY etc.: Anchor Books Dubleday.

17. Komitet po economicheskoy politike i strategicheskomu planirovaniyu Sankt-Peterburga (2014). Strategiya economicheskogo i sotsialnogo razvitiya Sankt-Peterburga na period do 2030 goda [Komitee for Economic Policy and Strategic Planning of Sankt-Peterburg (2014). Strategy of Economic and Social Development for SaintPetersburg for the Period till the Year 2030]. Available: http://sp.lifttothefuture.ru/ uploads/priority/files/8a6583f47913432de477c7bd87b606990080fa9c.pdf

18. Kvint, V. (2016) Strategy for the Global Market. Theory and Practical Applications. NY: Routlege (fragments). Available: https://books.google.ru/books?id=b_GoCgAA QBAJ\&pg=PT2\&lpg=PT2\&dq=Strategy + for + the + Global + Market + Theory + and + P ractical+Applications\&source (accessed: 26 September, 2016).

19. Lappo, G. (2012). Goroda Russii [Cities of Russia]. Moskva: Novyy Chronorgaf.

20. Mamaev B. \& Working Group (2013). Strategiya razvitiya Samarsko-Tol'yatiskoy aglomeratsii [The strategy of development for the Samara-Togliatti agglomeration]. Available: // http://www.svplotnikov.ru/upload/tmp/.pdf (accessed: 26 September, 2016).

21. McCann, E. \& Paddison, R. (2014). Conclusion: Engaging the Urban World. In: Paddison, R. \& McCann, E. (eds.) Cities and Social Change. London etc.: Sage Publications.

22. Ministerstvo economicheskogo razvitiya (2015). Plan meropriyatiy ("dorozhnaya karta") "Razvitiye aglomeratsiy v Rossiyskoiy Federatsii" (proyeckt) (Ministry for Economic Development. Plan of Actions ("The Road Map") "Development of Agglomerations in the Russian Federation” (draft)). Available: http://economy.gov.ru/wps/ wcm/connect/pdf (accessed: 26 September, 2016).

23. Mumford, L. (1938 / 1970). The Culture of Cities. San Diego, NY, London: A Harvest. HBJ Book.

24. Population Reports (1981). Special topics (15-19). Baltimore: Johns Hopkins University.

25. Pain, K. (2015). Megaregions Imaginaries: Excursions through a Dialectical Maze. Available: http://www.lboro.ac.uk/gawc/rb/rb451.html (accessed: 26 September, 2016).

26. Regional Plan Association (2014). Shaping the Region. Available: http:// library.rpa. org/pdf/RPA-Shaping-the-Region.pdf (accessed: 26 September, 2016).

27. Durieux, R.L. (2016). La Brooklinization: As Paris expands, what will become of its notorious suburbs? Available: http://qz.com/352031/as-paris-expands-what-will-become-of-its-notorious-suburbs/ (accessed: 26 September, 2016). 
28. Scruggs, G. (2016). The “Grand Paris" era begins. Cityscope, 08.01.2016. Available: http: http://citiscope.org/story/2016/grand-paris-era-begins (accessed: 26 September, 2016).

29. Strategy Report (2009). Metropolitan Region BerlConceptualin. Brandenburg. Available: http://www//Downloads/mdb-bb-gl-publikationen-strategyreport_engl.pdf (accessed: 26 September, 2016).

30. Shchitinsky, V. (2013). Gorodckie aglomeratsii v Rossii: mif ili realnost? [Agglomerations in Russia: A Myth or a Reality]. Available: www.leontief-centre.ru/UserFiles/ Files/shitinsk.ppt (accessed: 26 September, 2016).

31. The 100 Year Anniversary of the Consolidation of the 5 Boroughs into NY City (1998). Available: https://web.archive.org/web/20071011221627/http://nyc.gov/html/nyc100/ html/classroom/hist (accessed: 26 September, 2016).

32. United Nations Conference on Housing and Sustainable Urban Development (2016). Draft New Urban Agenda. Available: https://www.habitat3.org/the-new-urban-agenda (accessed: 26 September, 2016).

33. World Travel Awards (2016). Saint Petersburg Takes Top Title at World Travel Awards Europe. Available: www.worldtravelawards.com (accessed: 26 September, 2016).

34. Yavlinskiy, G. (2014) Bolshoy Peterburg. XXI vek. Kontseptualnaya strategiya razvitiya megapolisa [Greater St. Petersburg. XXI Century. The conceptual Strategy for the Megapolis Development]. Available: http://www.yabloko.ru/files/bspb21.pdf (accessed: 26 September, 2016). 